\title{
Analysis on China's Export Brand Strategy
}

\author{
You Qiujin ${ }^{1, \text { a }}$, Chen Chun $^{1}$ \\ ${ }^{1}$ Wuhan University of Science and Technology, Wuhan, China
}

\begin{abstract}
The development of the Internet era has brought about a globally integrated economic and trade system, which has enabled the economies of many countries to develop by leaps and bounds. Of course, under such an economic system, China's economy has also benefited a lot. However, compared with other countries, China's has many shortcomings in brand building. Although China's is the world's largest country in terms of exports, most of these exports are based on cheap labor costs and low-tech content, while the exports of branded products only account for a small part. This paper analyzes the current problems and deficiencies of China's exports in brand and brand strategy by studying the competitiveness of Chinese export brands in the international market, and analyzes the solutions to these existing or possible problems.
\end{abstract}

\section{INTRODUCTION AND LITERATURE REVIEW}

The rapid economic development has made competition between products increasingly fierce. The most important factor for a company to win the market is product quality. When information is asymmetric, the corporate brand can represent product quality. The same is true for export products. The strength of the corporate brand can be reflected in the international market of the product. Competitive. d. The lack of brand awareness and brand positioning of China's foreign trade enterprises has led to the fact that the independent innovation and core competitiveness of products are at a disadvantage compared to foreign brands, which largely hinders the development of China's foreign trade economy. If China's wants to avoid trade price wars in the international market and reduce trade frictions between them, it must develop corporate brands and implement effective brand strategies.

Yang Kai (2016) ${ }^{[1]}$ believes that the differences between products are becoming smaller and smaller, and competition in the international market has entered brand competition from initial price competition, quality competition, and service competition. Wang Hongyan $(2018)^{[2]}$ believes that brand can be used as an important indicator to measure a country's economic level and sustainable development capabilities. In this study, Wang Ying and Liu Jiahong (2018) ${ }^{[3]}$ believe that if an exporting foreign trade company wants to gain a greater competitive advantage in international competition, the company must expand the brand's influence in the market in order to strive for more advantages.

\section{Overview of China's's export tRade}

A. China's export scale is constantly expanding, but the potential risks cannot be ignored

TABLE I. 2010-2019 CHINA'S EXPORTS AND TOTAL TRADE

\begin{tabular}{|c|c|c|c|}
\hline $\begin{array}{c}\text { Time } \\
\text { (year) }\end{array}$ & $\begin{array}{c}\text { Total import and } \\
\text { export (USD } \\
\text { million) }\end{array}$ & $\begin{array}{c}\text { Total exports } \\
\text { (USD million) }\end{array}$ & $\begin{array}{c}\text { Import and export } \\
\text { balance (USD } \\
\text { million) }\end{array}$ \\
\hline $\mathbf{2 0 1 9}$ & 4576126.04 & 2499028.93 & 421932 \\
\hline $\mathbf{2 0 1 8}$ & 4622444.13 & 2486695.71 & 350948 \\
\hline $\mathbf{2 0 1 7}$ & 4107138 & 2263344.92 & 419552 \\
\hline $\mathbf{2 0 1 6}$ & 3685557.41 & 2097631.19 & 509705 \\
\hline $\mathbf{2 0 1 5}$ & 3953032.72 & 2273468.22 & 593903.73 \\
\hline $\mathbf{2 0 1 4}$ & 4301527.34 & 2342292.7 & 383058.05 \\
\hline $\mathbf{2 0 1 3}$ & 4158993 & 2209004 & 259015 \\
\hline $\mathbf{2 0 1 2}$ & 3867119 & 2048714 & 230309 \\
\hline $\mathbf{2 0 1 1}$ & 3641864 & 1898381 & 154897 \\
\hline $\mathbf{2 0 1 0}$ & 2974001 & 1577754 & 181507 \\
\hline
\end{tabular}

As shown in the form, China's export trade volume is increasing year by year, and the growth rate is also increasing, but the future trade pattern is not too optimistic, and various risks cannot be ignored. For example, in the recent Sino-US trade war, one of the main reasons is that the trade volume between China and the United States 
reached 637.97 billion US dollars, and the deficit was as high as 377.23 billion US dollars.

TABLE II. TOP 10 CHINA'S TOTAL EXPORTS IN 2018

\begin{tabular}{|c|c|c|c|c|c|}
\hline country & $\begin{array}{c}\text { United } \\
\text { States }\end{array}$ & Japan & Korea & Netherlands & Germany \\
\hline value & 5076 & 1644.2 & 978.5 & 938.6 & 817.7 \\
\hline country & Mexico & India & Vietnam & $\begin{array}{c}\text { United } \\
\text { Kingdom }\end{array}$ & Canada \\
\hline value & 741.5 & 720.2 & 585 & 567.18 & 547.4 \\
\hline
\end{tabular}

\section{B. Severe dependence on foreign investment and low added value}

Although China's economy is developing rapidly, the development of local brands is not ideal. Reliance on foreign resources has been continuously strengthened, blindly exploring foreign advanced technologies and brands, but ignoring the research and development of inhouse technology, making the products produced not only have lower technical content than foreign brands, but the added value of the products is even greater. It can be ignored, and it also puts China's export brands at a disadvantage in the international market competition, and it is not conducive to the development of China's export brands.

\section{China's export trade market is too concentrated}

According to relevant data analysis, among the top ten countries in China's export trade, there are six in Asia, two in Europe, and one each in North America and Oceania. Among them, China's export trade with the United States accounted for the largest share, reaching 507.6 billion U.S. dollars, followed by Japan at 164.42 billion U.S. dollars and South Korea at 97.85 billion U.S. dollars, and the growth rate of trade continued to increase at a high rate. For example, the Netherlands, India, and Vietnam have only exported about 80 billion US dollars to these countries, but their sales are very fast. Compared with the previous year's export value, they have increased by $32.80 \%, 18.75 \%$, and $16.90 \%$ respectively.

\section{Problems and Causes of Lack of Brand Strategy in ChinA's Export Trade}

\section{A. Problems Existing in China's Export Trade Brand Strategy}

1) Unstable brand positioning, lack of brand image shaping

The instability of China's brand positioning is manifested in two aspects: First, brand products lack core competitiveness. Many foreign trade companies in China's cannot take a long-term vision in the process of brand development. They only take into account the meager interests in front of them, and continue to expand their brand positioning, which seriously affects the construction of brand core competitiveness and hinders brand development. Second, the company does not have a thorough understanding of brand positioning. Many companies think that since they have established a brand, they should build the brand as high-end as possible, and position the brand in any area that is popular. This is actually a big misunderstanding. The positioning of the brand should be based on the characteristics of the brand and its consumption. The group locates, rather than blindly follow the crowd.

2) Insufficient $R \& D$ capabilities of export companies and insufficient brand innovation

The weak level of technological research and development of China's export enterprises and the weak awareness of independent innovation are the main reasons for the lack of independent brands and low brand value content in China's. According to statistics, there are only a few thousand enterprises in China's that have independent intellectual property rights, accounting for less than three ten thousand of the total number of enterprises in the country, and $99 \%$ of enterprises have not applied for their own patents. In the high-tech field, more than half of foreign-funded enterprises have applied for invention patents, while Chinese domestic-funded enterprises "have manufacturing but no creation, knowledge but no property rights." The weak R\&D investment and output capacity of Chinese enterprises, and the current dominant position of traditional brands, the lack of innovation in new brands, and the slow development of new brands make it difficult for "Made in China" brands to compete with internationally renowned brands in the international highend market.

3) Lack of awareness of development and management of export brand strategy

At present, Chinese enterprises have no long-term and systematic strategic planning for brand core value positioning and brand extension, which has caused the image of Chinese brands in the international market to be blurred and brand communication frustrated. Although many companies have developed their own brands, they gradually lose competitiveness and withdraw from the market due to lack of follow-up funds, technical support, or insufficient brand maintenance management experience These are all manifestations of China's weak awareness of brand development and management for export commodities.

4) Insufficient brand awareness of self-protection

With the increasingly fierce competition in the global market in the era of knowledge economy, Chinese companies have begun to realize that brands are playing an important role in occupying the international market. There are still cases in which well-known brands with a certain degree of popularity and market share are registered by foreign companies. The typical Chinese watch industry occupies $80 \%$ of the production volume and $30 \%$ of the output value of the international watch market. The scale and quality have reached the mature conditions for creating an international brand. However, it is still preemptively registered by the "patent blockade" of foreign companies. The lack of brand protection awareness makes Chinese enterprises controlled by multinational companies, restricted to low-value-added OEM production links, and loses the advantage of promoting potential brands to the world. 


\section{B. Reasons for the lack of China's brand strategy in export trade}

1) China's only focuses on export sales performance, but ignores the establishment and development of the brand

Our country's export policy for earning foreign exchange urges companies to put export and foreign exchange creation first; however, due to the overall, longterm, and slow effect of brand strategy, companies believe that building a brand is the future. The current situation of China's encouragement of exporting foreign exchange has made enterprises eager for quick success and quick gains and will not spend a lot of time on brand building. To a certain extent, it has distorted the development path of foreign trade enterprises.

\section{2) Insufficient corporate decision makers}

The leader's ability to identify the market, organization and management ability and market development ability directly affect the implementation of brand strategy. The key issue facing China's established well-known brands is how to maintain the brand's lasting competitiveness. Most foreign trade companies rely on a single quality management to shape the core competitiveness of their brands and meet international standards. The establishment of a strong brand requires comprehensive shaping and management from product positioning, business planning, marketing, cost control, etc., and continuous innovation and improvement with market changes.

\section{3) The business itself has limitations}

Most of China's foreign trade enterprises are small in scale, limited in resources, and weak in production technology, resulting in insufficient ability to withstand risks in daily operations. Company culture is very important for the sustainable and healthy development of a company. A good corporate culture should complement the corporate brand. However, most companies in China's still have insufficient understanding of corporate culture due to various reasons, especially for consumers. There is a lack of cultural connotation.

\section{COUNTERMEASURES OF EXPORT BRAND STRATEGY}

TABLE III. IMPORT AND EXPORT VOLUME OF THE WORLD' $\mathrm{S}$ THREE LARGEST ECONOMIES IN THE PAST TWO YEARS

\begin{tabular}{|c|c|c|c|c|c|}
\hline \multicolumn{2}{|l}{ Total import and export value } & \multicolumn{3}{c|}{ Total export value } \\
\hline time & Japan & $\begin{array}{c}\text { United } \\
\text { states }\end{array}$ & time & Japan & $\begin{array}{c}\text { United } \\
\text { states }\end{array}$ \\
\hline May-20 & 92094.62 & 3436.29 & May-20 & 41856.22 & 1445.14 \\
\hline Apr-20 & 113432.23 & 3520.23 & Apr-20 & 52060.3 & 1511.33 \\
\hline Mar-20 & 127089.05 & 4227.08 & Mar-20 & 63580.54 & 1901.84 \\
\hline Feb-20 & 115359.89 & 4581.77 & Feb-20 & 63212.85 & 2117.52 \\
\hline Jan-20 & 121775.15 & 4629.34 & Jan-20 & 54312.02 & 2104.46 \\
\hline Dec-19 & 133113.44 & 4686.67 & Dec-19 & 65760.97 & 2114.96 \\
\hline Nov-19 & 128464.02 & 4621.96 & Nov-19 & 63790.08 & 2105.71 \\
\hline Oct-19 & 131411.81 & 4638.35 & Oct-19 & 65761.72 & 2104.03 \\
\hline Sep-19 & 128670.65 & 4662.59 & Sep-19 & 63689.96 & 2092.1 \\
\hline Aug-19 & 124296.5 & 4718.12 & Aug-19 & 61387.2 & 2105.17 \\
\hline Jul-19 & 135408.01 & 4719.65 & Jul-19 & 66434.6 & 2104.62 \\
\hline Jun-19 & 125820.64 & 4702.57 & Jun-19 & 65850.87 & 2092.54 \\
\hline May-19 & 126410.9 & 4769.62 & May-19 & 58378.41 & 2128.52 \\
\hline Apr-19 & 132696.01 & 4643.76 & Apr-19 & 66642.94 & 2065.36 \\
\hline
\end{tabular}

\begin{tabular}{|c|c|c|c|c|c|} 
Mar-19 & 138870.02 & 4741.21 & Mar-19 & 66236.02 & 2107.16 \\
\hline Feb-19 & 124420.74 & 4682.02 & Feb-19 & 63854.19 & 2084.75 \\
\hline Jan-19 & 125670.76 & 4671.93 & Jan-19 & 55746.79 & 2065.34 \\
\hline Dec-18 & 140993.23 & 4721.29 & Dec-18 & 70217.94 & 2056.61 \\
\hline Nov-18 & 145932.96 & 4695.99 & Nov-18 & 67918.15 & 2079.76 \\
\hline Oct-18 & 149431.9 & 4769.4 & Oct-18 & 72434.63 & 2101.24 \\
\hline
\end{tabular}

\section{A. Corporate strategy}

1) Clarify brand positioning and find out the competitive advantage of product differentiation

For a successful brand, its positioning needs to consider two aspects: first, the positioning of the brand must well show the competitive advantage of the product differentiation of its brand; second, segmentation according to the target consumer group of the product. The market, looking for market vacancies. The positioning of the brand is to link these two aspects and transform the attributes of the product into the interests of consumers. From the perspective of consumers, we use quantitative market research methods to conduct market research on consumer groups. According to the survey data, we analyze consumers of different types, different levels of consumption, and different consumption preferences and habits to further understand consumers' desire to consume from brands. What value satisfaction is obtained in the focus of brand positioning is to grasp consumers' buying psychology, stimulate consumers' desire to buy, and turn it into consumer impulse.

2) Persist in the brand strategy's innovation of the times, and strengthen scientific research and development capabilities

Export companies can produce a wide range of visibility through successful innovative knowledge management, thereby gaining the ability to create new brand value. Although foreign companies in China's also have their own brands, their core technologies are relatively scarce, resulting in a relatively low product value-added rate of their own brands, and the value of the brand can only be reflected in the product trademark symbols. The reason for this situation is that foreign companies in our country have only focused on absorbing and training management and marketing talents for a long time, ignoring technical talents in product innovation, design, and R\&D. To solve such problems, companies need to pay attention to the training of brand talents, and even more. Absorption and training of brand research and development professionals.

3) Insist on brand marketing innovation and strengthen brand management awareness

Self-owned brands can reflect the strength of a country's enterprise. It is not only an intangible asset of an enterprise, but also an embodiment of a country's product competitiveness in the international market. Traditional marketing methods can no longer adapt to the requirements of the current era of economic globalization. As a developing country, China must have a deep understanding of this. An extremely important reason for the success of our country's successful independent brands is that the brand managers who lead them have a strong brand awareness, which allows them to pay close attention to changes in market demand, so that they can predict the market, walk in the forefront of the times, and are 
committed to Develop first-class products, surpassing the world's advanced level.

4) Strengthen the awareness of intellectual property protection of China's export enterprises and insist on brand maintenance

a) Maintenance of brand quality: The essence of brand-name products being welcomed by consumers lies in consumers' recognition and trust of high-quality brand products. Enterprises want to occupy a certain market share for a long time, and continuously consolidate and improve product quality to achieve their goals. An indispensable condition.Change number of columns: Select the Columns icon from the MS Word Standard toolbar and then select "1 Column" from the selection palette.

b) Maintenance of brand technology: Brand technology is the soul of a brand. If a company wants to stand on the market, seize market share, and defeat competitors, it must maintain its development technology, and protect and maintain its technological leadership and uniqueness according to market development needs.

c) Brand maintenance, crack down on counterfeiting and counterfeiting: Companies can improve their counterfeiting technology through channels such as products and brand logos. At the same time, they also need to inform consumers how to distinguish between genuine and fake products, popularize consumers' brand recognition capabilities, and protect their legitimate rights and interests through legal measures.

d) Brand crisis management.: Establishing a corporate brand awareness of crisis management and establishing a crisis management mechanism are indispensable mechanisms for escorting corporate brands. Companies can establish brand crisis management departments, establish a complete information detection system, and at the same time strengthen the staff's crisis awareness and handling capabilities, and comprehensively protect brand development.

\section{B. National strategy}

It can be seen from the table that there is a huge difference between China's exports to Japan and the United States in trade volume. The reason for this difference is precisely because of the Sino-US trade war, which directly affects China' s export trade volume and also affects most of our foreign trade companies. It caused a huge impact. Therefore, to increase the company's ability to withstand risks, the most important thing is to improve product quality and build our own brand. At the same time, a good corporate brand can also enhance the company's own competitiveness when exporting.

1) Establish a leading industrial structure with independent intellectual property rights at the core

The progress of national science and technology is closely linked with the development of economy and investment in science and technology. The government can issue fiscal guidance policies to encourage enterprises to become the mainstay of technological innovation. The national government should also work hard to adjust the structure of the three major industries, and establish a system with high-tech innovative technology industries as the forefront, manufacturing industries and basic industries as the pillars, and full-scale development of the service industry. Strongly support China's foreign trade enterprises to establish a leading industrial structure whose core is independent intellectual property rights.

2) Create a good export brand cultivation mechanism

The government should encourage the establishment of export brand cultivation mechanisms at different levels and in different directions in accordance with the reality of the unbalanced development of our industry. Continue to improve the basic work of China's independent brand creation through the establishment of foreign marketing systems and service agencies; the government should take the lead in purchasing export brands under the same conditions in different types of government procurement; encourage famous brand export companies to integrate assets and optimize resource allocation, Promote its development and enhance its international competitiveness; encourage the construction of national independent brands.

\section{3) Increase policy support}

When China's export enterprises develop their own brands, they need a lot of funds to maintain, and they need to implement long-lasting and cumbersome investment activities. At present, the problem that most Chinese enterprises generally face is insufficient funds, which directly restricts the branding of enterprises. Therefore, the government should promote the development of China's export enterprise brand through policy leverage and financial support. For example, allow enterprises to enjoy export inspection exemption or preferential treatment when export declaration; give preferential policies and taxation and financial support to well-known brand export enterprises.

\section{CONCLUSION}

Through analysis, it can be seen that China' s exports are currently under great pressure. To increase the international competitiveness of commodities, it is necessary to create unique brands of China's. The national government and enterprises need to make efforts at the same time to continuously improve the rigid quality of China's export products, and fully tap the beneficial value of the brand strategy for China's import and export products.

\section{REFERENCES}

1. Yang Kai. A Preliminary Study on the Brand Strategy of Foreign Trade Export Enterprises [J]. Chinese and Foreign Entrepreneurs, 2016(18): 14.

2. Hongyan Wang. The status quo and countermeasures of China's export trade implementing brand strategy[J].Modern Enterprise,2018(01):22-23.

3. Ying Wang, Jiahong Liu .Analysis of Brand Strategy of China' s Foreign Trade Commodities[J].Modern Business,2018(06):34-35. 